\title{
T-CELL LARGE GRANULAR LYMPHOCYTIC LEUKEMIA - CASE REPORT
}

\begin{abstract}
Sandra Kojić Katović ${ }^{1}$, Ankica Vasilj ${ }^{1}$ and Goran Rinčić ${ }^{2}$
${ }^{1}$ Department of Cytology, Sestre milosrdnice University Hospital Centre, Zagreb, Croatia; ${ }^{2}$ Department of Hematology, Sestre milosrdnice University Hospital Centre, Zagreb, Croatia

SUMMARY - T-cell large granular lymphocytic leukemia (T-LGLL) is an uncommon but probably underdiagnosed disease caused by clonal proliferation of large granular lymphocytes. Diagnosis is typically based on the high number of morphologically characteristic lymphoid cells and finding of an abnormal immunophenotype by flow cytometry. Because of its relatively indolent clinical behavior, observation is often an appropriate therapy. Here we present a case of a 53-year-old male admitted to the hospital because of abdominal pain. Blood examination revealed mild mycrocitic anemia and multiplied lactate dehydrogenase level. Abdominal ultrasound showed splenomegaly of $16 \mathrm{~cm}$, with no lymphadenopathy. Fine needle aspiration of bone marrow revealed hypocellular marrow with $50 \%$ of atypical lymphoid cells. There were $81 \%$ of atypical medium sized granular lymphocytes with irregularly shaped nuclei in peripheral blood, so the cytologic diagnosis was lymphoproliferative process. Bone marrow biopsy showed nodular and interstitial proliferation of small, partially atypical T lymphocytic cells positive for CD2, CD3, CD5, CD8, granzyme and TIA, and negative for hairy cell markers, CD10, MUM 1, bcl 1, CD4 and CD56. The finding was consistent with T-LGLL. Due to splenomegaly, the patient was treated with cyclosporine and gradually reduced dose of corticosteroids, leading to regression of splenomegaly and normalization of lactate dehydrogenase level.
\end{abstract}

Key words: Leukemia, Large Granular Lymphocytic; Cell Proliferation; Lymphocytes; Immunophenotyping; Flow Cytometry; Anemia; Splenomegaly; Bone Marrow, Aspiration and Biopsy; Case reports

\section{Introduction}

T-cell large granular lymphocytic leukemia ( $\mathrm{T}$ LGLL) is a heterogeneous disorder affecting equally men and women, and characterized by expansion of the monoclonal population of large granular lymphocytes in peripheral blood ${ }^{1}$. Since proteins such as TIA1, granzyme $B$ and granzyme $M$ are usually expressed, immunohistochemical analysis of bone marrow biopsies with antibodies to these antigens and CD8 can be used to confirm the diagnosis of

Correspondence to: Sandra Kojić Katovic, $M D, P h D$, Department of Cytology, Sestre milosrdnice University Hospital Centre, Vinogradska c. 29, HR-10000 Zagreb, Croatia

E-mail: sandra.kojic.katovic@kbcsm.hr

Received September 9, 2016, accepted May 22, 2017
T-LGLL ${ }^{2-4}$. T-LGLL is distinctive from aggressive NK cell leukemia based on their unique molecular and clinical features ${ }^{5}$. The clinical course of T-LGLL is indolent in most cases ${ }^{6}$. CD8 $8^{+}$T-LGLL is associated with mild to moderately stable lymphocytosis, neutropenia, splenomegaly, and occasionally anemia ${ }^{7}$. Lymphadenopathy is very rare ${ }^{1}$. In addition, T-LGLL demonstrates strong association with autoimmune diseases, especially rheumatoid arthritis ${ }^{7}$, and less frequently systemic lupus erythematosus, Hashimoto's thyroiditis and Sjögren's syndrome ${ }^{8}$. The monoclonal expansion of $\mathrm{CD}^{+} \mathrm{T}$-LGLL has been reported only sporadically in the literature ${ }^{6}$. It is marked by association with malignant diseases and characteristically shows the absence of cytopenia, splenomegaly and autoimmune disease ${ }^{6}$. 


\section{Case Report}

A 53-year-old male was admitted to the hospital because of abdominal pain. Blood examination showed mild microcytic anemia (hemoglobin level was 125 $\mathrm{g} / \mathrm{L}$ and $\mathrm{MCV}$ was $73.8 \mathrm{fL}$ ). There was no leukopenia or thrombocytopenia. The lactate dehydrogenase (LDH) level were multiplied (626 U/L). The value of beta 2 microglobulin was also increased $(4.8 \mathrm{mg} / \mathrm{L})$. Due to microcytic anemia, gastroscopy and colonoscopy were performed to reveal chronic gastritis. Colonoscopy findings were normal. Abdominal ultrasound revealed splenomegaly of $16 \mathrm{~cm}$, with no lymphadenopathy. Computed tomography scan of the thoracic region showed axillary lymphadenopathy, probably reactive. In addition, there was lymphadenopathy on the left side of the neck and in the right groin. Fine needle aspiration (FNA) was performed to show reactive lymphocytic hyperplasia. There were $81 \%$ of atypical medium sized granular lymphocytes with irregularly shaped nuclei in peripheral blood (Fig. 1), which were immunocytochemically positive for CD3 (Fig. 2), so the cytologic diagnosis was lymphoproliferative process. FNA of the bone marrow showed $50 \%$ of atypical small to medium sized lymphoid cells with irregularly shaped nuclei and a moderate amount of cytoplasm containing large granules (Fig. 3), partially positive on acid phosphatase stain. Bone marrow reticulum also contained epitheloid histiocytes and multinuclear phagocytes and hystiocytes. Bone marrow biopsy showed nodular and interstitial proliferation of small,

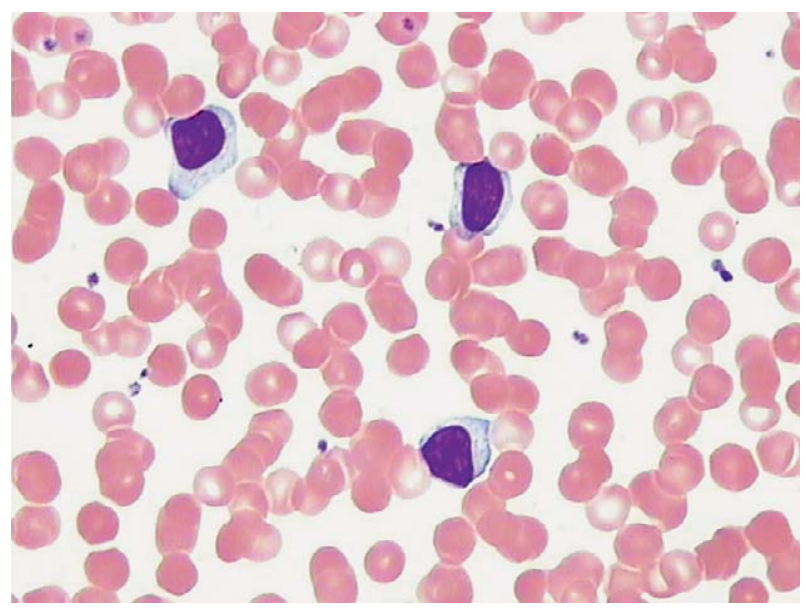

Fig. 1. Large lymphocytic granular cells in peripheral blood (May-Grünwald-Giemsa, X1000).

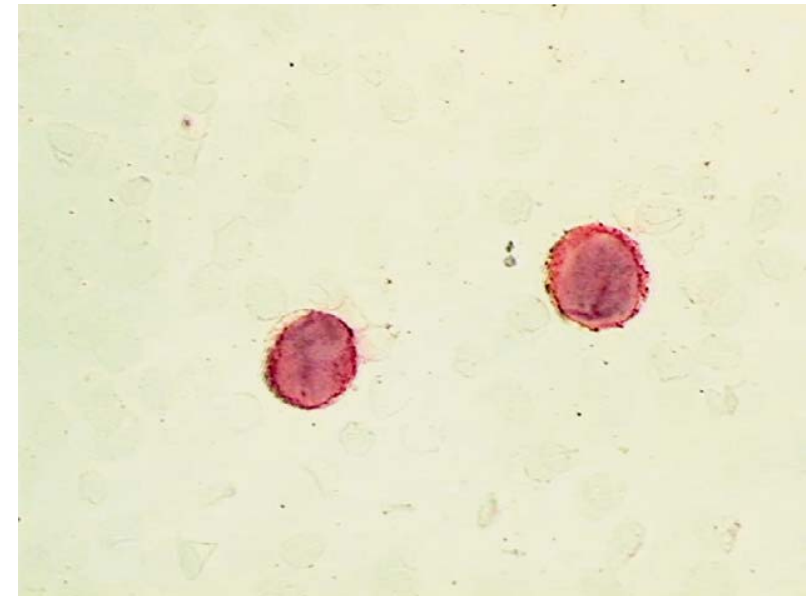

Fig. 2. Large lymphocytic granular cells: immunocytochemistry; CD3 positive cells (LSAB, X1000).

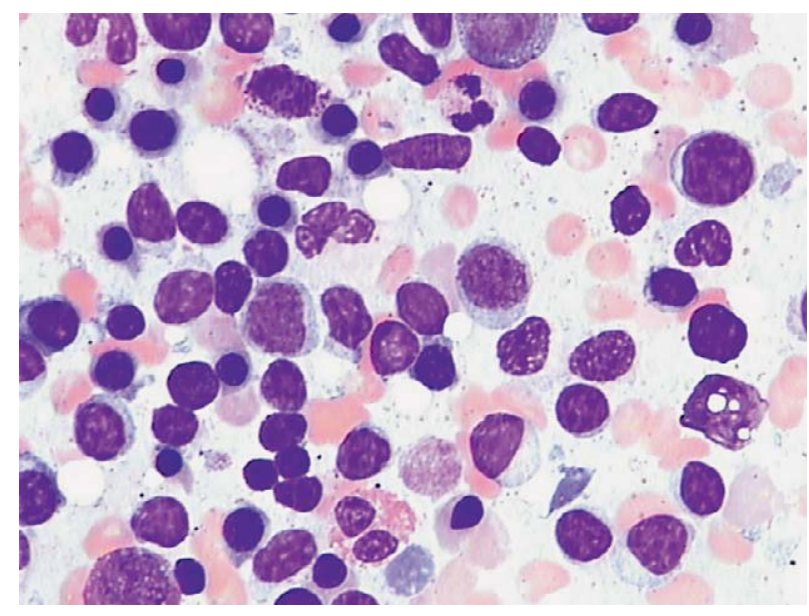

Fig. 3. Large lymphocytic granular cells in bone marrow (May-Grünwald-Giemsa, X1000).

partially atypical $\mathrm{T}$ lymphocytic cells positive for $\mathrm{CD} 2$, CD3, CD5, CD8, granzyme and TIA and negative for hairy cell markers, CD10, MUM 1, bcl 1, CD4 and CD56. The finding was consistent with T-LGLL. Due to splenomegaly and abdominal pain, the patient was treated with cyclosporine $2 \times 100 \mathrm{mg}$ daily with regular monitoring of drug concentration in serum and gradually reduced dose of corticosteroids, which have recently been discontinued. This therapy led to regression of splenomegaly and normalization of LDH level about 6 months after therapy introduction. A year after the diagnosis, the patient is on cyclosporine alone, he is well, with no symptoms of the disease. 


\section{Discussion}

T-cell large granular lymphocytic leukemia accounts for about $2 \%$ of cases of monoclonal proliferation of B cell, T cell and NK cell mature lymphocytic leukemia ${ }^{1,6}$. The etiology of the T-cell form of LGL leukemia is not known. The terminal effector memory phenotype of leukemic LGL suggests response to chronic antigen exposure. This hypothesis is also supported by the finding that sequencing of the antigenspecific portion of the T-cell receptor suggested nonrandom antigen-driven clonal selection. The peptide(s) involved in initial expansion have not been discovered. However, some data suggest that chronic activation by a virus with structural similarity to the human T-cell leukemia virus retroviral family may contribute to this process ${ }^{10}$. Although uncommon, this malignancy is probably underdiagnosed, despite the fact that it has been recognized as a well defined clinical entity in the World Health Organization classification since $2008^{1}$. However, it has been described in all age groups, the majority of cases occur in the middle and elderly age groups ${ }^{1,9}$, as in our patient. He was admitted to the hospital because of unclear abdominal pain, probably caused by splenomegaly. Peripheral blood smear showed $81 \%$ of atypical medium sized granular lymphocytes with irregularly shaped nuclei, so the cytologic diagnosis was lymphoproliferative process and bone marrow FNA was required. The aspiration revealed hypocellular marrow with $50 \%$ of atypical small to medium sized lymphoid cells. Because of the lack of specific antibodies, bone marrow biopsy was performed and based on immunohistochemical profiles (T lymphocytic cells positive for CD2, CD3, CD5, $\mathrm{CD} 8$, granzyme and TIA and negative for hairy cell markers, CD10, MUM 1, bcl 1, CD4 and CD56), the diagnosis of T-LGLL was established. Treatment of T-LGLL depends on whether the patient is asymptomatic or the disease is causing problems, such as recurrent infections, anemia, thrombocytopenia or splenomegaly. Usually, this type of leukemia shows indolent course, so it may not need to be treated right away. Rarely, the disease behaves aggressively and has to be treated with more intensive chemotherapy ${ }^{10}$. Our patient was treated with cyclosporine due to splenomegaly and abdominal pain and a gradually reduced dose of corticosteroids, which have recently been discontinued. About 6 months after therapy introduction, sple- nomegaly regression and LDH level normalization occurred; the patient is in remission with cyclosporine alone in therapy.

In conclusion, the case presented shows that $\mathrm{T}$ LGLL represents a diagnostic and therapeutic challenge. Morphology alone is not sufficient for accurate diagnosis, thus additional methods such as immunocytochemistry and immunophenotyping are required.

\section{References}

1. Swerdlow SH, Campo E, et al., editors. WHO Classification of Tumors of Haematopoietic and Lymphoid Tissues. $4^{\text {th }}$ edn. Lyon: IARC; 2008.pp. 272-3.

2. Morice WG, Jevremovic D, Hanson CA. The expression of the novel cytotoxic protein granzyme $\mathrm{M}$ by large granular lymphocytic leukaemias of both T-cell and NK-cell lineage: an unexpected finding with implications regarding the pathobiology of these disorders. Br J Haematol. 2007;137:237-9. [PubMed] DOI: $10.1111 /$ j.1365-2141.2007.06564

3. Morice WG, Kurtin PJ, Tefferi A, Hanson CA. Distinct bone marrow findings in T-cell granular lymphocytic leukemia revealed by paraffin section immunoperoxidase stains for CD8, TIA-1, and granzyme B. Blood. 2002;99:268-74. [PubMed]

4. Osuji N, Beiske K, Randen U, Matutes E, Tjonnfjord G, Catovsky D, et al. Characteristic appearances of the bone marrow in T-cell large granular lymphocyte leukaemia. Histopathology. 2007;50:547-54. [PubMed]

DOI: $10.1111 /$ j.1365-2559.2007.02656

5. Lim MS, de Leval L, Quintanilla-Martinez L. Commentary on the $2008 \mathrm{WHO}$ classification of mature T-and NK-cell neoplasms. J Hematop 2009;2:65.

DOI: $10.1007 / \mathrm{s} 12308-009-0034-\mathrm{Z}$

6. Lima M, Almeida J, Dos Anjos Teixeira M, Alguero Md Mdel C, Santos AH, Balanzategui A, et al. TCR $\alpha \beta^{+} / \mathrm{CD} 4^{+}$large granular lymphocytosis: a new clonal T-cell lymphoproliferative disorder. Am J Pathol. 2003;163:763-71. [PMC free article] [PubMed]

7. Melenhorst JJ, Sorbara L, Kirby M, Hensel NF, Barrett AJ. Large granular lymphocyte leukaemia is characterized by a clonal T-cell receptor rearrangement in both memory and effector CD8(+) lymphocyte populations. Br J Haematol. 2001; 112:189-94. [PubMed]

8. Friedberg JW, Mauch PM, Rimza LM, et al. Lymphomas: non-Hodgkin's lymphomas. In: Devita VT Jr, Lawrence TS, Rosenberg SA, editors. (2008). Cancer: Principles \& Practice of Oncology. $8^{\text {th }}$ edn. Philadelphia: Wolters Kluwer Health/ Lippincott Williams \& Wilkins; 2008; pp. 2098-143.

9. Olteanu H, Karandikar NJ, Eshoa C, Kroft SH. Laboratory findings in CD4+ large granular lymphocytoses. Int J Lab Hematol.2010;32:9-16.DOI: 10.1111/j.1751-553X.2008.01109x

10. Lamy T, Loughran TP Jr. How I treat LGL leukemia. Blood. 2011;117(10):2764-73. DOI: 10.1182/blood-2010-07-296962 
Sažetak

\section{T-STANIČNA LEUKEMIJA VELIKIH GRANULIRANIH LIMFOCITA - PRIKAZ SLUČAJA}

\section{S. Kojić Katovic, A. Vasilj i G. Rinčić}

T-stanična leukemija velikih granuliranih limfocita je rijetka i vjerojatno nedovoljno dijagnosticirana bolest uzrokovana klonalnom proliferacijom velikih granuliranih limfocita. Dijagnoza se temelji na povećanom broju morfološki karakterističnih limfatičnih stanica i nalazu abnormalnog fenotipa na protočnoj citometriji. S obzirom na indolentan klinički tijek bolesnika se često samo prati. U ovom radu prikazan je 53-godišnji bolesnik koji je hospitaliziran zbog bolova u abdomenu. Laboratorijski nalazi pokazivali su srednje tešku mikrocitnu anemiju i višestruko povećanu laktat dehidrogenazu. Ultrazvukom abdomena verificirana je splenomegalija od $16 \mathrm{~cm}$, bez limfadenopatije. U razmazu periferne krvi nađeno je oko $80 \%$ srednje velikih atipičnih limfatičnih stanica nepravilnih jezgara, dok je punkcija koštane srži pokazala 50\% opisanih atipičnih limfatičnih stanica. Biopsijom koštane srži nađena je nodularna i intersticijska proliferacija malih, dijelom atipičnih T limfocita pozitivnih na $\mathrm{CD} 2, \mathrm{CD} 3, \mathrm{CD} 5, \mathrm{CD} 8$, granzim i TIA, a negativnih na biljege za leukemiju vlasastih stanica, CD10, MUM1, bcl 1, CD4 i CD56, što odgovara dijagnozi T stanične leukemije velikih granuliranih limfocita. Bolesnik je zbog splenomegalije liječen ciklosporinom i postupno snižavanim dozama kortikosteroida, što je dovelo do smanjivanja veličine slezene i normalizacije laktat dehidrogenaze.

Ključne riječi: leukemija velikih granuliranih limfocita; stanična proliferacija; limfociti; imunofenotipizacija; protočna citometrija; anemija; splenomegalija; koštana srž, aspiracija i biopsija; kortikosteroidi; prikazi slučaja 